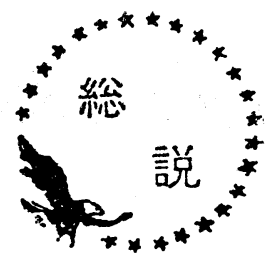

合成液体燃料の開発と石油工業

一昭和50年 6 月 30 日受理一

\section{1. 合成液体燃料開発の必要性}

石炭, 油母頁岩 (オイルシェール) などから各種の プロセスによって製造される液体然料は，過去に际い ては人造石油の名で呼ばれ，しばしば戦争と結びつけ てその開発が推進された。例えば第 2 次世界大戦にさ いしては，ドイッ，イギリス，日本，その他の国々で 人造石油工業の振興に多大の努力が傾注されたことが 想起される。

戦争終結のあと, 人造石油事業は敗戦国に括いては 軍事的予防措置という理由で禁止され，また戦勝国に おいても経済的に不利という理由でほとんど放棄され てしまい，わずかに長期的観点の下に始められた米国 鉱山局の石炭液化研究プラントの運転も間もなく休止 された。ただ南ア共和国のみはそのきわめて安価な石 炭を拠りどころとして，Fischer-Tropsch 式石油合成 工場を建設，運転し，今日まで続いている。

このよらにして，第 2 次世界大戦終了からアラブ石 油ショック発生にいたる約30年のあいだ，石炭（ある 場合には天然ガス）からの人造石油製造は, 経済的に きわめて不利なために実際的でないとされ，わずかに 天然ガス拉よび石油の供給が外から得られず，安価か つ豊富な石炭資源のみを保有するような地域（典型的 な例が南ア共和国 SASOL とされる）飞扮いてのみ 成立しらるとされていた。

しかしながら，このような事情は 1973 年 10 月のア ラブ石油ショック発生いらい全く一変し, 石炭その他 の原料からの石油製造に対する関心は，とくに石油輸
入国に怙いて急速かつ異常なまでに高まってきた。こ れは，OPEC 諸国によって強引に引上げられた石油 の高価格によってもたらされた経済的重圧を，石油に 代るエネルギー源の開発によっては㸚かえしたいとい ら国家的要求に基づくものであり，また同時に OAP $\mathrm{EC}$ による石油禁輸の不安を解消し，さらに可能なら ば，いずれは到来するであろら地球上の石油不足にそ なえて，長期的なエネルギー源確保対策をたてて置き たいといら願いから来るものである。

現在のような原油の高価格が続くかぎり，そしてま た長期的には石油資源の有限性といらことを考えるか ぎり，液体然料補給策の一環として石炭液化を再び取 上げるのはきわめて当然であり，また必然である。た だ，過去に和ける人造石油工業が軍事的観点から推進 されたのに対し，現在ないし将来のそれは純粋に経済 的可能性に基づいて推進されるね゙ならないといら点 が，常に留意されねばなるまい。

なお，合成原油開発の必要を理由ゔける根拠の一つ である，地球上の石油および天然ガス資源の有限性に 関しては，本誌の他の論文に沶いて詳しく述べられる であろらから，ここにはただそれらの統計值のみを示 すことにしたい。

世界の石油資源については多くの人々が度々論じて

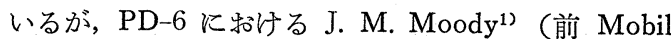
Oil Corp. 副社長）の報告によれば，表1のような 統計数字が与えられている。

埋蔵量/産油量の比 (R/P 值) は目下のところアラ
表 1 世界の石油埋蔵 量1)

地 域

米国を含む北米

ソ連，中国等

中 東

そ の 他

世界 全 体
既産油量

(A)

149

63

94

99

415
確認特よび

(B)

80

142

587

201

1,010
筑極産油量

(A) $+(\mathrm{B})$

229

205

681

300

1,415
（1972年現在, 単位億 $t$ )

\begin{tabular}{|c|c|c|}
\hline $\begin{array}{l}\text { 替 発 } \\
\text { 在 } \\
\text { (C) }\end{array}$ & $\begin{array}{l}\text { 見 } \\
\text { 量 }\end{array}$ & $\begin{array}{l}\text { 総 窮 } \\
\text { 産 油 } \\
(\mathrm{A})+(\mathrm{B})+(\end{array}$ \\
\hline 201 & & 430 \\
\hline 478 & & 683 \\
\hline 179 & & 860 \\
\hline 456 & & 756 \\
\hline 1,314 & & 2,729 \\
\hline
\end{tabular}


ブ石油ショックの影響が解消しないために增減傾向が やや安定しないが，統計によれば 1973年度 31.2，19 74年度 35.1 であった。

\section{表 2 世界の天然ガス埋蔵量 ${ }^{2}$}

\begin{tabular}{|c|c|c|c|}
\hline 地 & & 採可量 (兆 $\mathrm{ft}^{3}$ ) & $\begin{array}{l}\text { 世界全体に対す } \\
\text { る比率 }(\%)\end{array}$ \\
\hline 中 & 東 & 728.3 & 31.2 \\
\hline ソ & 連 & 632.0 & 27.5 \\
\hline 北 & 米 & 349.0 & 15.2 \\
\hline 西 & 欧 & 181.4 & 7.9 \\
\hline アフ リ & 力 & 175.1 & 7.6 \\
\hline 南アジア，極 & 怄東 & 91.9 & 4.0 \\
\hline 南 & 米 & 47.2 & 2.1 \\
\hline オーストラリ & & 36.9 & 1.6 \\
\hline 中 & 国 & 30.0 & 1.3 \\
\hline 東 & 欧 & 24.2 & 1.1 \\
\hline 合 & 計 & $2,296.0$ & 100.0 \\
\hline
\end{tabular}

天然ガス資源に関しては，同じく PD-6 と拈いて 英国 BP 社の M. A. Kirkby 2) が詳しく論じ，これま で Weeks その他が推定した $(5,000 \sim 12,000) \times 10^{12}$ $\mathrm{ft}^{3}$ に対してやや控え目の值 $2,296 \times 10^{12} \mathrm{ft}^{3}$ (約 65 兆 $\mathrm{m}^{3}$ ) を示した。これはごく大まかな計算によって約

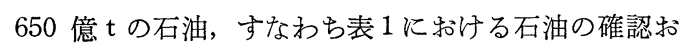
よび推定埋蔵量の $1 / 2$ 以上に相当するといってょかろ ら。

\section{2. 世界における合成液体燃料開発の現状}

石油原油以外の原料, 例えば石炭類, 油母頁岩 oil shale, 油砂 oil sand, 天然アスファルト, 天然ガス などから製造した炭化水素油を総称して合成液体燃 料, ある場合には合成原油 synthetic crude oil 之呼 ぶ。

\section{1 石炭からの合成液体然料}

世界の石炭類の総埋蔵量は McKetta 等 ${ }^{33}$ の計算に よれば 7 兆 6,600 億 $\mathrm{t}$ といわれ, 石油の埋蔵量約 1 , 000 億 $\mathrm{t}$ に比し70 80倍であり，またその賦存も地球 上に比較的ひろく分布しているので, 石油が現在占め ているエネルギー源としての地位をいつの日か石炭か らの合成液体然料が受けつぐであろらことは疑いの余 地がない。しかも, 前述のと扣り, 石炭からの液体然 料製造技術については過去に执いて多くの，また現在 においても僅かながら工業的実績があるので, 経済的 その他の条件が整うかぎり，しだいに重要な役割を演 ずるにちがいない。

よく知られるょうに, 石炭類から液体燃料を得るル

\section{表 3 世界の石炭埋蔵量 ${ }^{3)}$}

（1972年現在，石炭および褐炭）

\begin{tabular}{|c|c|c|c|}
\hline 国 名 & 埋 蔵 量 & 年間出炭量 & 年間消費量 \\
\hline 国 & 13,000 & 5.4 & 4.6 \\
\hline 本 & 200 & $0.2^{*}$ & 0.9 \\
\hline 西ドイッ & 2,600 & 1.6 & 1.2 \\
\hline その他 & 50,800 & 18.4 & 17.4 \\
\hline 世界全体 & 76,600 & 25.4 & 24.1 \\
\hline
\end{tabular}

一トは各種あるが, 主要な反応工程は液相ならびに気 相高圧水素添加（もしくは水素化分解）と $\left(\mathrm{CO}+\mathrm{H}_{2}\right)$ 混合ガスからの接触合成であり, これらにさらに石炭 類の膏温乾留もしくは低温乾留, 乾留生成物であるコ 一クからの合成ガス $\left(\mathrm{CO}+\mathrm{H}_{2}\right)$, あるいは水素の製 造などの工程が適宜組合わされる。

a）石炭液化の歷史と現状

水素化分解法による石炭の液化は, はじめドイツに 物いて Bergius により発明され，I. G. 社によって工 業化されたが，のち英国，日本等においても実施され た。第 1 次水素化分解は液相で行なわれ, 主として重 質油が得られる。さらに高品質ガソリンを目的とする 場合にはこの重質油の第 2 次水素化分解を気相で触媒 存在下に行なら。

PD-22 に拈ける H.Schulzid に上れば, 1945 年以 前に石炭水素添加工場がドイッ国内に12プラント（合 計能力 423 万 $\mathrm{t} / \mathrm{Y}$ ), 海外飞 1 プラント (能力 15 万 $\mathrm{t} / \mathrm{Y}$ ) 存在したという。戦後, 西ドイッ国内の若干のプラン トでは石油残渣油の水素添加が1962年にいたるまで行 なわれた。

抽出と水素化を組合せて石炭を処理する方式（例え ばPott-Broche 法, Uhde 法, IG-Kurz-Hydrierung 法など）の開発も行なわれたが，ガソリン製造を目的 とする場合にはこれらは適切な方式ではない。

現在, エホルギー源特よび化学原料の供給と環境保 全対策といら観点から, 抽出と穏和な水素添加を同時 に起こさせるような条件で石炭を処理するプロセスが 米国拉よび西独に扔いて見直され, 低 $\mathrm{S}$ 低灰分の重質 燃料油製造法として適当と考えられて, その技術開発 が国家的にも推進されている。

さらに水素添加法の拡張によって, 芳香族性高オク タン価ガソリンもしくは化学用 BTX 製造原料となり らるような留出油を有利製造しえないかどらかが検 討されている。この考え方は, 安価な高灰分石炭が豊 富な南ア共和国などで興味が持たれ，SASOL でも研 
究されている。

石炭の溶剤抽出々批出物利用に関する研究は英国に 特いても現在行なわれている由である。

b ） 米国に打汗る研究開発

早くから世界第 1 位の石油産出拉よび消費国として の地位を誇っていた米国が，石炭からの合成液体然料 製造にほとんぞ関心を示さなかったのは当然である。 ただ，第 2 次世界大戦当時まで, 英国で開発された低 温乾留法に興味が持たれ，いくつかの独自の低温乾留 プロセスが米国内で開発されたといら歴史はある。

第 2 次大戦のあと，括そらくは軍事的関心も持たれ たからであろらが，米国鉱山局 Louisiana (Missouri) 実験所に Bergius 式石炭液化試験プラントが, 機器 の一部と人員の一部もドイツから移されて, 建設さ れ，米国炭の液化試験が行なわれた。しかし天然石油 に比し生産費が著しく高いことが判明して, やがて中 止された。

また1940年代から1950年代にかけて，C.C.C. プロ 七スの開発研究 (Charleston, W.V.) が行なわれた が，これまたコスト高といら理由で中止された。別 に, Texas 褐炭の低温乾留工場が Texas Powder Co. と Aluminium Co. of Amer. の共力でRockdale に建設され，操業されたが, タールの処理で行 詰まってしまった。

石油精製工業に括いても数社が石炭液化の研究を取 上げたが，多数の特許発明が登録されたのみに終っ た。

1960年代に入ってから，米国に打ける石炭利用研究 の推進は石炭研究局 Office of Coal Research の手に よって行なわれているが6)，一連の開発研究の目標 は，主として固体石炭のクリーンな液体燃料への変換 に和かれている。単位操作およびプロセス段階の設計 と選定にさいしては，次の諸点が考慮される。

1. 第 1 次基準としての原料炭の性状（品位, $\mathrm{S}$ 含 有量, 灰分など）に応じてプロセス選定を行なうこ と。例えば無煙炭の液化などは研究対象外とする。

口. 要求される製品の性状, 種類に応じてプロセス を選定すること。一連のガス，液体および固体が市場 から要求される場合には低温乾留法を適当とする。各 種プロセスによって石炭から製造しうる液体然料は, 無灰低 $\mathrm{S}$ の, 融点 $200^{\circ} \mathrm{C}$ の固体, 石油系残渣重油と同 等の低 $\mathrm{S}$ 無灰重質燃料, 家庭用燃料油括よび芳香族性 灯油之同等の低沸点芳香族性留出油, もしくはガソリ ンの沸点範囲内に入る軽質芳香族性留出油胃などであ る。触媒の利用によって, 生成油の沸点範囲の選定,
所望の特定製品の収率向上なども可能となろう。

八. 石炭 $\rightarrow$ 液体生成物の第 1 次工程としては水素を 用いない，非接触的熱的プロセスが重視されるである う。FMC-COED プロセス (多段流動乾留法)，Toscoal プロセス（頁岩油製造の Tosco プロセスの転 用）などがこれである。急速加熱，小接触時間を適用 すれば, プロセスが簡単化されることが期待される が，Garrett R. \& D. (Occidental 石油の子会社) は このようなプロセス（Flash Pyrolysis プロセス）を 目ざしている。急速加熱を水素気中で行なら方式も可 能で, City College of New York に执いて研究さ れている。

石炭からの液収率を上げようとすれば，当然，水素 を用いるばならないが，そのさい，非接触的な方式と 触媒を用いる方式とがある。

SRC プロセス (Solvent Refined Coal Process) は, 古く1930年代にドイッで考案された Pott-Broche 法の変形といらべきもので，70-200atm の水素気 中, 沸点 $200^{\circ}-450{ }^{\circ} \mathrm{C}$ の溶媒を用いて石炭を溶解し, 灰分を残渣として分けたのち, 溶媒 (再使用)を蒸留 によって除き，無灰低 S の低融点固体燃料を得る。こ のプロセスは Gulf Oil Co. の子会社 PittsburgMidway Coal Mining Co. が, O.C.R. からの援助 $(2,800$ 万 \$) を得て， $50 t / D$ $/$ ラントを建設し, 試験 中である。先進的プロセスの一つと考えられる。

Exxon あるいは Consol プロセスに扔いても, 石 炭の溶解を水素気中で行ならほか, 溶媒を水素伝搬体 として役立てるために溶媒水素化工程を別につけ加え ている。

高圧下, 触媒を用いる石炭液化プロセスとしては, Hydrocarbon Research Inc. の H-Coal プロセス (沸騰触媒床), Gulf Oil Co. の CCL プロセス (石 油系重質油の脱硫触媒と同様な触媒を用いる)，鉱山 局の Synthoil プロセスなどが開発されつつある。特 殊な触媒としては Consolidation Coal Co. が試験中 の塩化亜鉛触媒がある。

二: 第 1 次工程に括ける水素消費量の多少もプロセ ス選定上の重大項目である。例えば乾留法では水素消 費は 0 である。溶媒による抽出, 穏和な接触処理など の場合には水素消費は原料石炭に対し1-3\%で足りる が，軽質留出油の生成を望む場合にはこれは15\%程度 にもなる。水素化反応ははげしい発熱を伴ならので, 触媒劣化の原因となる過度の温度上梨を防ぐために， 熱のコントロールを巧みに行ないらるような水素一石 炭の接触方法が考案されねばならない。また水素発生 
る。

その他, Fischer-Tropsch 法の新展開として, 西ド イッでは小分子量のオンフィンのような有機化学製品 を直接合成する方式，一旦生成した直鎖状炭化水素の 熱分解によってエチレンを高収率で得るプロセスの組 合わせなどが検討されている。

また 100bar 以上の高圧下でルテニウム触媒を用 い, Ziegler 法低圧ポリエチレンと同様なポリメチレ ンを直接合成するプロセスが Pichler 等 ${ }^{81}$ とって開 発された。

d）人造石油のコスト

石炭ないし褐炭からの人造石油のコストを一義的に いうことは難しいと思われるが, 比較的新しく Pichler 等》が試算した結果を示すと表 4 のと扔りである。

表 4 人造石油のコスト試算 ${ }^{7}$

(1974年 1 月現在, 西ドイッ)

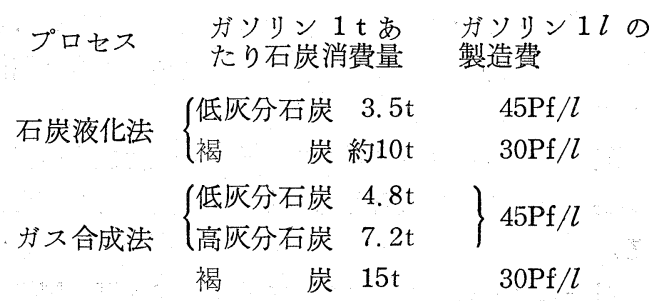

ただしプラント能力 250 万 $\mathrm{t} / \mathrm{Y}$

褐炭価格 $10 \mathrm{DM} / \mathrm{t}\left(0.5 \mathrm{Pf} / 10^{3} \mathrm{kcal}\right)$

石炭価格 $98 \mathrm{DM} / \mathrm{t}\left(1.42 \mathrm{Pf} / 10^{3} \mathrm{kcal}\right)$ ……低灰分炭, 液化用

$51 \mathrm{DM} / \mathrm{t}\left(1.1 \mathrm{Pf} / 10^{3} \mathrm{kcal}\right)$ ……高灰分炭, ガス化用

$1 \mathrm{DM}=100 \mathrm{Pf} \fallingdotseq$ 約 102 円 56 銭

表 4 の試算に拉いて，ガソリン製造費に占める原料 石炭の費用は，液化法の場合には和上そ50\%，また合 成法の場合には括よそ60\%である。

1974年 1月現在で, 西ドイッに拈ける自動車ガソリ ン価格は 14-24Pf/l であったから, 石炭 : ガソリン の価格比は約 $1: 3$ ，これが 1970 年には $1: 1$ ，また 1945年以前には $1: 12$ ないし 1：14であった。したが って合成石油成立のためには原料石炭を現状よりもさ

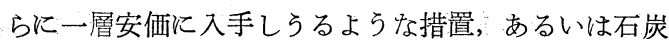
原単位を格段に切下げらるようなプロセスの開発が考 えられねばならない。例えば原子炉の高温を石炭ガス 化に利用しうるならば, 前記のガス合成法の石炭原単 位は $4.8 \mathrm{t}$ らか $3.5 \mathrm{t}$ に，また褐炭ならば $15 \mathrm{t}$ から 10 ～12 $\mathrm{t}$ 亿低減させうる筈である。

\section{2 油砂からの原油回収}

油砂 oil sand は必ずしもカナダ Athabasca の特 産物之は考えられないが，その埋蔵資源量が余りにも 莫大であるために, oil sand といえば Athabasca oil sand を意味するかのように受取られる場合が多い。 すなわち Humphrey 等9にとよれば, Alberta 州の総 埋蔵量は 9,000 億 $b b l$ 之見積られ，そのうちの約 2,500 億 $b b l$ が現在の技術で回収可能であるといら。これ らの数字のみから判断すれば, 世界最大の炭化水素資 源といっても決して誇称ではない。そのため一部の人 々は, この資源の開発利用に関して安易な構想を画く かも知礼ない。乙かし，実際に Athabasca に打いて その開発に取組んでいる GCOS ${ }^{9}$, Syncrude Cana$\mathrm{da}^{9)}$, Amoco Production ${ }^{10)}$ 等の人々の報告は, oil sand 開発事業がいかにきびしい条件の下に進められ ねばならぬかをきわめて詳細に明らかにした。

すでによく知られているように ${ }^{1112)} ， 1967$ 年いらい 操業中の唯一の油砂処理工場は GCOS 社 (Great Canadian Oil Sand Ltd.) の Athabasca 工場であ り, 同所では露天掘りした油砂から $\mathrm{NaOH}$ 含有熱水 によって原油を抽出している。原油回収能力は各種の 困難を解決, 克服しつつ徐々に高められ，現在では表 5 亿示されるように, 当初の設計能力に比し，11\%增 の $50,000 \mathrm{bbl} / \mathrm{D}(6,600 \mathrm{t} / \mathrm{D})$ となっている。

\section{表 5 GCOS 社の合成原油生産能力9)}

$\begin{array}{lll}\text { 年 次 } & \begin{array}{c}\text { 生 } \\ b b l / \mathrm{CD}\end{array} & \begin{array}{l}\text { 量 } \\ \mathrm{t} / \mathrm{CD}\end{array} \\ 1968 & 24,100 & 3,150 \\ 1969 & 27,300 & 3,600 \\ 1970 & 32,700 & 4,300 \\ 1971 & 42,100 & 5,500 \\ 1972 & 50,900 & 6,700 \\ 1973 & 49,900 & 6,600\end{array}$

採掘一熱水抽出法は含油量 $6 \%$ 以上 (埋蔵量計算は 5 $\%$ 以上について算出される), 最高 $18-20 \%$ で，層の 厚さ 30-45m の鉣床に適用される。そのさい被覆層 （覆土）の厚さは $46 \mathrm{~m}$ 以内であることが望ましく，そ れ以上飞厚い場合には地層内採油法 in-situ recovery process の方が経済的であろうといわれる。油少 : 被 覆層の比は平均 $2: 1$ であるから, 例えば合成原油 55 , $000 \mathrm{bbl} / \mathrm{D}(7,300 \mathrm{t} / \mathrm{D})$ の抽出工場では, 概算して

$120,000 \mathrm{t}$ (油仯) $\times 2+60,000 \mathrm{t}$ (覆土) $=300,000 \mathrm{t}$ という, 多量の土纱を運搬しなければならない。合成 原油 $1 \mathrm{t}$ 当り固体 $38 \mathrm{t}$ というのが実績である。しかも 
廃砂は環境保全規制にそって処分しなければならな い。

また一部の地域に拈いては, 油砂が多量の同伴水を 含むため, 凍結が地下 $3-3.6 \mathrm{~m}$ にも達する冬期に は，それが採掘上の大きな困難を発生させる。かくて 採掘および運搬のシステムをいかに組むかがきわめて 重要な問題である。GCOS はようやくこのシステム を確立しえたという段階であろう。

油仯から回収された重質油（ビテューメン）の加工 (高品位化) については，すでに本誌その他で度々紹 介されているので,ここには繰返さない。ただ熱水抽 出とディレードコーキングを組合せた現 GCOS プラ ントにおける物質処理量を示すと表 6 のようになる。

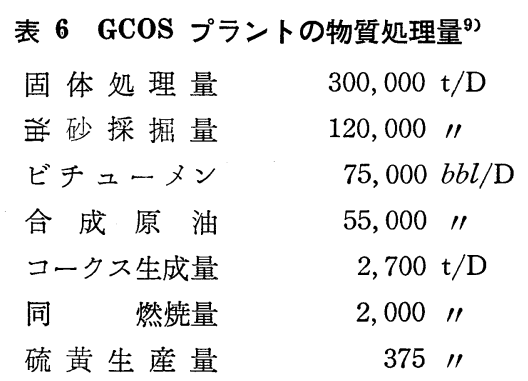

第二の油少処理工場 Syncrude Canada Ltd. は能 力 $125,000 \mathrm{bbl} / \mathrm{D}(16,500 \mathrm{t} / \mathrm{D})$ で近く操業開始に入る 予定であり，このほかさらに少なくとも2プラントの 建設計画が進行中と伝えられる。

以上はいすれも露天掘り可能な浅層の油少を処理す るプラントであり, さらに梁層 (46m以上) の油砂に 対してはいわゆる in-situ process によらねばならな い。その原理は, 油艀に吸蔵されているビチューメン ないし重質油に何らかの方法で流動性を持たせたのち に，公知の採油法を適用するものである。溶媒（炭化 水素など）を圧入する方法，高温スチームを送入する 方法, 空気吹込みによりビチューメンを一部然焼さ せそその熱によってビチューメンに流動性を持たせる 方法などが考えられるが，Amoco Production Co. は Gregoire Lake 地区で1958年から空気吹込みによ る加熱方式で現場実験を始めた。これに対し Imperial Oil Ltd. は Cold Lake 地区でスチーム吹込み方式の 現場実験を1960年代から行なった。

両社とも規模を順次拡大した実験を成功裡に重ねて いるが，商業生産に入るためには建設および操業準備 に 8-10 年を必要とすると見こんでいる。Amoco Production 社の実験成績の 1 例 ${ }^{10)}$ は表 7 のと㧊りで
あった。

\section{表 7 地層内採油法の実験成績 ${ }^{10)}$}

(1/2エーカー・5点方式による結果)

$\begin{array}{lc}\text { 原 油 存 在 量 } & 90,000 \mathrm{bbl} \\ 65.6^{\circ} \mathrm{C} \text { 以上に加熱された } & 53,000 \prime \prime \\ \text { 原油の量 } \\ \text { 原 油 燃 焼 量 } & 6,600 \prime \prime \\ \text { 全原油に対する\% } & 7.3 \\ \text { 原 油 回 収 量 } & 29,000 \mathrm{bbl} \\ \text { 全原油に対する\% } & 32 \\ \text { 加熱された原油に対する\% } & 55\end{array}$

表から知られるように, 地層内採油法における原油 回収率は，採掘一熱水抽出法に抒ける 92-93\% という 高い回収率に比べるときわめて低いのは止むを得ない が，この方式が石炭の坑道掘りのよらな採掘法によら なければ開発不可能な深層に適用しらる方式であるこ と，また環境保全という観点から問題点が少ないこと 等の特徵を持っているので, 将来の発展に大きな期待 が寄せられている。

後述の頁岩油生産に関しても地層内採油技術の開発 が要望されていることと思い合せて, 興味ある点であ る。

以上のように, カナダのオイルサンド資源の開発は 着々進捗中であり, 同国の石油供給に寄与するところ はきわめて大きいと思われるが，実際にはきびしい天 然条件下での難事業であることを理解しなければなら ない。

\section{3 頁岩油の開発}

油母頁岩からの重質炭化水素油の回収は，すでに第 2 次世界大戦以前に英国スコットランド，スエーデ ン, バルチック沿岸国, 満州などで実施され, とくに 満州撫順に拈けるそれはわが国との関係深いものであ った。近年, 中東その他の産油量増大にともなって, これらの頁岩油生産は拉括むね忘れ去られていたが, ただ米国のみはコロラドその他における莫大な油母頁 岩 (正しくは泥灰岩) の利用を1950年代から熱心に考 えていた。 ${ }^{11)}$ 例えば Union Oil Co. はコロラド河上 流の East Parachute Creek に打いて企業化研究を 行ない, その成果をすでに 1959年第 5 回世界石油会議 (New York) に報告した。 ${ }^{13)}$

世界全体の頁岩油資源 (可採量) は扣よそ 3,200億 $k l$ といわれ, そのうちの約 $1 / 2,1,653$ 億 $k l$ はコロ ラド, ユタ, ワイオミングの米国 3 州に埋蔵されてい る。(表 8 参照) 


\section{表 8 世界の頁岩油資 源 ${ }^{14)}$}

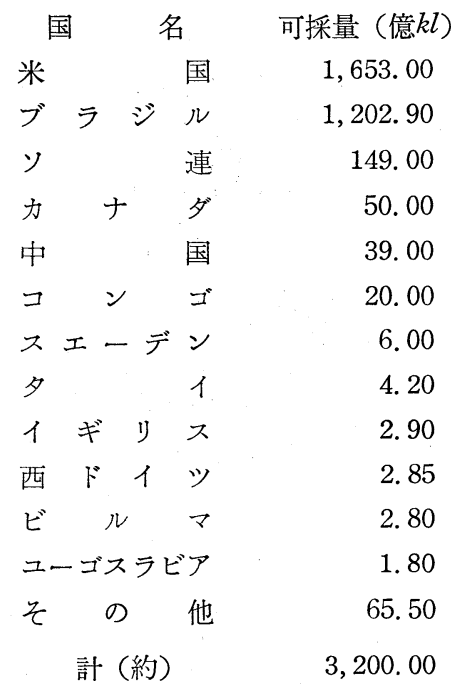

a) 採掘一乾留法

米国の頁岩油開発は, 政府の立場では鉣山局 Laramie 石油研究センターが主となって, 鉣石採掘, 砕 石, ガス燃焼式下向き乾留炉による内熱乾留試験等を コロラド河上流 Anvil Points のパイロットプラント を用いて実施した。 ${ }^{11)}$ 本施設はその後, Socony Mobil, Humble 等, 17 企業から成る 共同研究組合 Paraho プロジェクトによって引継がれ, 乾留プロセスについ て若干の改良が加えられた。近く経費 750 万をを投じ て処理能力 $370 \mathrm{t} / \mathrm{D}$, 直径 $8.5 \mathrm{ft}$ の直立炉による半 工業化試験に移行する由である。15)

民間企業としては, Union Oil Co. が頁岩油開発 にもっとも古く関係した企業の一つと考えられるが， 同社が East Parachute Creek の実験所で開発した 乾留炉は, 独特の rock pump を用いた上向き内熱乾 留炉で, 技術的には企業化に必要な資料はすでに十分 整備されており，1979年までに奏装置を建設したい意 向を表明している。

つぎに有力なプロセスは，Atlantic Richfield（装 置運転を担当), Oil Shale Corp., Standard Oil (Ohio), Cleveland Cliffs 製鉄などの諸社が共同した 研究組合 Colony Development Operation が能力 1,000 t/D の半工業化試験プラントを用いて開発した Tosco II プロセスである。本プロセスは, 横型傾斜 回転炉内で熱媒体としての磁製球体と頁岩細粉とを接 触させて乾留を行なら方式であり, 目下, 実装置の設 計中である。

さらに, Superior Oil Co. の計画は若干特色があ
り，同社は坑道掘りによって頁岩を採掘するのと同時 に, 頁岩層中に混入している dawsonite を選別し, これから水酸化アルミニウムを製造しようとするもの で，内務省の承認が得られしだい，1980 年までに 50, $000 \mathrm{bbl} / \mathrm{D}$ のプラントを建設したいといら意向であ る。

b ）地層内採油法

前記のような採掘一乾留法の技術的進歩は著しいも

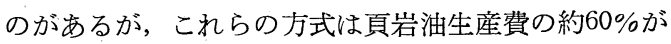
鉱石採掘打よび乾留に要するコストであるといら実情 から，これに代る方式として地層内採油法がすでに約 20年も前から関心を持たれていた。

地層内採油法の開発は，地層に割れ目をつける技術 （いわゆる fracturing）と地層内を加熱する技術の組 せ合によってなされる。前者は在来の水圧法, 火薬爆 発法などのほか特殊な方法としては地下核爆発があ る。また地層加熱は地下燃焼, 高温ガスないし液体の 圧入などによる。

Equity Oil Co. は Atlantic Richfield 社と協力し て，1968年以来, 加熱天然ガス, 高温スチームなどを 頁岩層に圧入し，乾留によって生成される頁岩油を採 油井から回収するといら原理に基づく Equity BX プ ロジェクトを実施したが，生成原油が良質である反 面, 十分な熱供給が難かしいといら久陷が改良でき ず，現在は休止されている。

Occidental Petr. Co. が 1972 年いらい研究中の方 式は，図1に示されるように，まず頁岩地層内に残柱 式採掘法によって乾留室 room を作り，その天井部 を火薬爆発を利用して破砕したのち, 地上から空気を 圧入して頁岩の一部を然焼させ，その熱によって乾留 を行ならといら方式である。

生成されるガス (燃料用) はガス回収孔を通じて, また頁岩油は空間部下底の貯留溝を経て回収される。 本方式では頁岩の一部は採掘されるので, 純粋な地層 内採油法とはいいがたいが，大量の鉱石の地上処理と いら難問題がほとんど解決された方式であるといえ る。経済性如何は, 乾留によって生成される頁岩油の 回収率をどこまで高められるかといら点にかかってい る。

米国鉣山局自身も1970年代初めから Rock Spring, Wyoming に打いて地層内乾留法の実験を行なって括 り，水圧による地層破砾と液体火薬の地層内爆発とを 組合せて, 割れ目 fracture を水平方向に進行させる 技術の開発に成功したので，近く大規模実験を行なう 計画であると。 


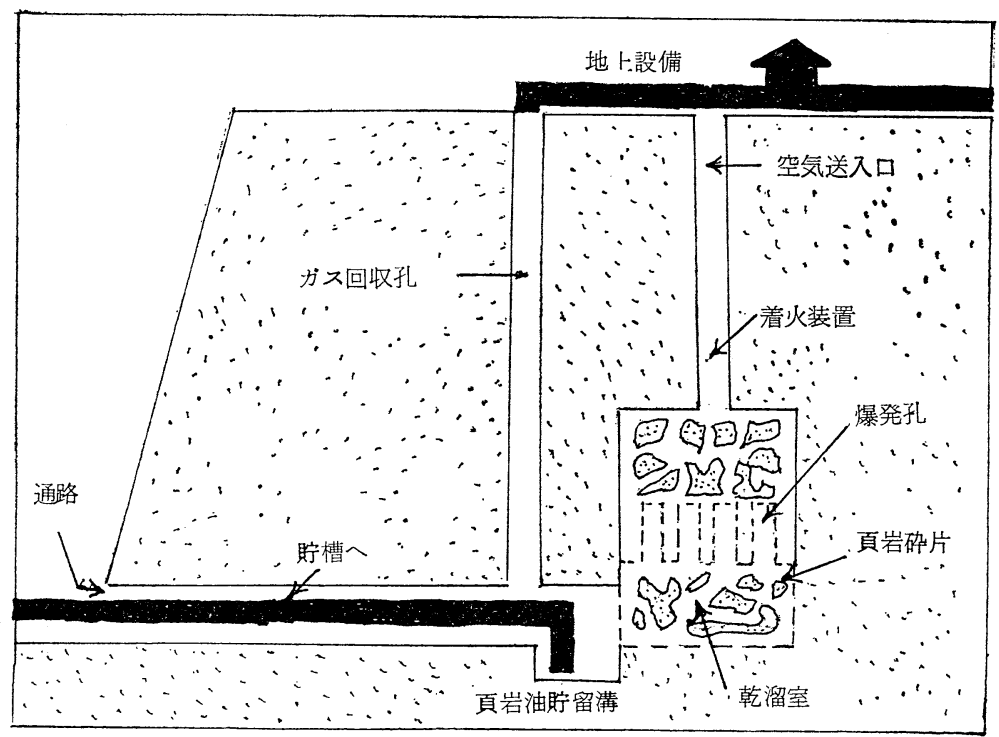

図 1 Occidental Petr. Co. の地層内採油法の原理

地層内採油法の決定版はまだ出現していないが，米 国政府関係者 (V.E. McKelvey) は，今後この方式 の開発を一層重視したい意向であることを，今次石油 会議 PD-20 の席上で言明していた。

米国に打ける頁岩油生産事業の発展規模は, 鉣区の 80\%を占有する米国政府の鉣区貸与条件，環境規制の 動向, 生産される原油の価格設定 (1974年現在で 8$9 \$ / b b l$ が要望されている), 企業の投資能力 (例えば $50,000 \mathrm{bbl} / \mathrm{D}$ プラント完成に約 6 億 \$以上を要す) な ぞによって左右されようが，企業化が比較的早いと予 想される Colony グループ, Union Oil, Superior Oil, Occidental Oil などは, いずれも1980年までに は実装置建設にふみきるものと思われ，それらの全生 産能力は 1985 年までに合計 50 万 b bl/D には達しょ う。それら以外にも新しい参入者がもちろんあるであ ろらが，100万 $b b l / D$ の水準達成のためには官民両側 からの一層の努力が必要とされよう。

頁岩油の開発に関連して，PD-22 の席上に和い て, A. G. Reyes (べネゼエラ) は, Orinoco 地区の 重質油 (油) 資源の利用について述べ，その埋蔵量 は 2.8 兆 $b b l$ にも達すること, 1980 年までに 12.5 万 $b b l / \mathrm{D}$ の生産プラントが完成されるはずであること等 を報告した。

また F.de M. Cheves (ブラジル) も頁岩油開発に ついて述べ, 現在 Petrosix プロセスによる開発実験 を行なっており，3 年以内に工業化試験プラントを完 成, 操業する予定であることを発表した。

\section{3. 代替エネルギー源の開発と石油工業}

現在, 世界に扣いて天然資源から供給される全エネ ルギーのらち，主要部分はまず石油によって賄なわ れ，ついでかなりの部分が石炭により賄なわれている ことは，表 9 に示されると扣りである。

\section{表 9 世界のエネルギー消費 ${ }^{3)}$ (1972年度)}

（石炭換算, 単位億 $\mathrm{t}$ )

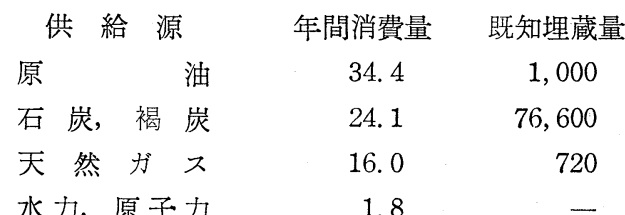

水力, 原子力

1.8

総計

76. 3

アラブ石油ショックの発生を待つまでもなく，この ようなエネルギー供給分担率の偏よりは本来不合理で あり，例えば資源埋蔵量に比例させるというような， 合理的比率の設定が可能ならば，これはエネルギー問 題解決の一指針となるか子知れない。しかし地球上に 扣ける資源，人口，工業などの分布や自然条件の不均 等はきわめて顕著であるから，問題はしかく簡単では ない。

石油工業の立場からは，各種代替エネルギー源の開 発によって，エネルギー供給に打ける石油の負担が軽 減されることは，広い視点に立って，また長期的観点 に立って，大いに歓迎されるべきである。 
もしまた，米国石油企業のように経済的技術的に十 分な余力を持つならば，自からも石油以外 $、$ ネルギ 一源の開発に参入しうるであろう。

それはともかく，石油に代るエネルギー源，とくに 炭化水素類の新しい供給源の開発が世界的にいか進 展して行くかは，わが国のみならず世界全体の石油工 業にとって最大の関心事である。これに関して，J. J. McKetta 等3) は“代替エネルギー源の開発が石油 工業に及活す影響” と題して, Gulf Publishing Co. に拈ける共同検討結果を述べた。

石油以外のエネルギー供給源として考慮の中に含め たものは, 石炭, 油母頁岩, 固体廃棄物, 水力, 核工 ネルギー，太陽エネルギー㧊よび地熱であった。内容 は主として米国の国内事情を論じたものであるが，以 下, 要点のみを摘記することにしたい。

イ、掘井扣よび採油

従来の方式で生産される石油括よび天然ガスが，今 日もな技世界でもっとも経済的なかつ入手可能なエ木 ルギー源を構成するという点は疑問の余地がない。も し工業国の経済が，たとえ減速された成長速度であっ ても，引続き伸びるものとすれば，もっとも低価格の エネルギー源が求められ，探索されるのが原則である から, 従来方式に上る石油生産の重視は今後も変らな 、筈であり，代替エネルギー源の開発が掘井搞よび採 油部門に顕著な影響を及价すことは紀元 2000 年前に は起こるまい。

例えば米国の頁岩油の場合, 生産量 100 万 $b b l / \mathrm{D}$ （約 15.9 万 $k l / D$ ) は 1985 年以前认は達成困難と考元 られる。このように従来方式と異なる新方式によって 生産される石油扔よびガスが全体の需給に寄与する率 は当分僅かであろら。

むしろ従来方式による石油供給力の増加の方に大き い努力が払われるであろう。例えば世界全体技よび米 国に挌ける1973-1974年の成果は次のと招りである。 掘井数 産油井 産油量 確認埋藏量

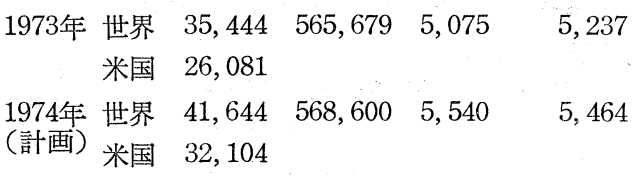

掘井数の增加が 1 年間で $+6,200$ 井 $(+17.5 \%)$ とい らのは，異常な伸びといえる。一方，米国の天然ガス に関しては，石炭系ならびに石油系 SNG が 1990年 頃には寄与しうるとしても, 既存天然ガスの減産傾向
が著しいので，新しい天然ガス採取技術（例えばロッ キー山脈地帯の緻密構造からのガス生産技術) の早急 な開発が望まれている。

ロ. 輸送一パイプライン

新しいエネルギー供給源の開発は, 米国ではパイプ ラインに重要な役割をになわせようとしている。

主としてエネルギーの緊急充足という見地から， Wyoming, Colorado 等の西部石炭を Arkansas, Texas，西北太平洋岸等にスラリ一輸送することが計 画され，1980年むでに年間 1.5-1.6 億 $\mathrm{t}$ の輸送を実 現させたいとしている。また頁岩油生産が1980年代初 めには実現する筈であるが，これにともなって頁岩油 のパイプライン輸送が必要となろう。例えば Colony プロジェクトを推進している Atlantic Richfield 社 は Colorado $\rightarrow$ Utah 間 192mile のパイプライン建設 をすでに申請している。

八. 天然ガスと NGL

天然ガス工業は新事態に直面して烈しい変化を受け つつあるが，これは主として，增大する新需要をまか ないきれないといらことから来て和り，多くの新しい 供給方式の開発を推進する必要にせまられている。例 えば涂ガスを LNG ないしメタノールに変えるこ と, 清浄燃料をガスに変換すること, $\mathrm{CO}_{2}, \mathrm{~N}_{2}, \mathrm{H}_{2} \mathrm{~S}$ 等の含量が多いために従来受入れられなかったような ガスをも販売用として精製すること等である。

代替エネルギー源の使用によってガス工業にもたら される影響は, さらに事務処理, プロセスの複雑化, 新しいタイプのガスの配給, 経済性, 政府規制等の点 ですこぶる多様である。

今後, 天然ガス工業は石油工業とともに, 新事態が もたらす2 次反応すなわち原材料, 労働力, 資金など に対する新需要を分かちあわねばなるまい。

\section{二. 精製抒よび加工}

表10から知られるように，石油製品の消費と石油精 製工業の関係をみると, いわゆる消費地精製主義が世 界各地域を通じて共通に貫かれている。すなわち，そ れらの石油精製工場に供給される石油資源の大部分は 主たる消費地の外に忿る。米国についていえば，現在 の消費量をもってすれば，米国の石油資源は10年足ら ずして枯渴することにならう。したがって, 新製油所 の建設は米国石油工業にとってはもはや魅力あるるの ではなくなった。むしろ石炭からの合成原油製造によ って，在来の製油所の操業維持を確保するのが，将来 対策として正しいと考えられる。

石炭液化が莫大な資本投下と長期間の企業化努力が 
表 10 世界の原油消 費 ${ }^{3)}$

（1972年度, 単位 億 $\mathrm{t}$ )

\begin{tabular}{|c|c|c|c|c|}
\hline 国 名 & $\begin{array}{l}\text { 石油埋 } \\
\text { 藏 量 }\end{array}$ & $\begin{array}{l}\text { 年 間 } \\
\text { 产油量 }\end{array}$ & $\begin{array}{l}\text { 精 製 } \\
\text { 能 }\end{array}$ & $\begin{array}{l}\text { 年 間 } \\
\text { 消費量 }\end{array}$ \\
\hline 国 & 49 & 4. 7 & 6.7 & 7.8 \\
\hline 本 & 0 & 0 & 2.0 & 2.4 \\
\hline 西ドイッ & 1 & 0.1 & 1.3 & 4 \\
\hline その他 & 718 & 20.5 & 19.7 & 14.4 \\
\hline 世界全体 & 768 & 25.3 & 29.7 & 26.0 \\
\hline 石炭換备 & 1,000 & 33.4 & 38.6 & 34.4 \\
\hline
\end{tabular}

必要なことは明らかであるが，しかも米国石油資本が これといかに意欲的に取組もうとしているかは，先に $2.1 \mathrm{~b})$ 項で述べたと拈りである。

なお，石油化学工業におよぼす影響について McKet ta 等は, 代替エネルギー源開発は石油化学原料の 供給にむしろ有利な影響を及ぼすとしている。例えば 石炭液化は BTX 製造原料としての軽質芳香族油, エ チレン原料としての $\mathrm{C}_{1}-\mathrm{C}_{4}$ パラフィンガス等の生成 を有利にさせるであろう。

以上が McKetta 等の考察結果であるが, 多分に米 国石油工業を背景にして導かれた結論であることを割 引いて考えねばならぬとしても, もって他山の石とし てよいのではなかららか。

\section{む す び}

“人類の福祉のための石油”をスローガンとして開 催された第 9 回世界石油会議は, いわゆるアラブ石油 ショックの余燼がまだ消え去らぬ時期にあったため, 石油执よび天然ガス資源の将来, 石油供給を補なう代 替エネルギー源，とくに合成液体然料の開発，これが 石油工業に及ぼす影響等に関連する講演ないし討論は 多数の出席者の関心の的であった。

それらの講演ないし討論を通じて概括的に把握しえ たことは次の諸点ではないかと思われる。

1）世界の石油資源は確認可採量として約 1,000 億 $k l$ であり, さらに今後の発見期待量があるとしても, 1980年代末ないし1990年代には石油供給窮屈化の時代 が近づくように思われる。しかし, 天然ガス資源も石 油の $1 / 2$ 以上を期待しうるので，これが石油を補なう 主要なエネルギー源の役割を果たすであろう。

2) 石炭資源は世界全体で 7 兆 $\mathrm{t}$ 以上もあるので, これから誘導される気体ないし液体合成然料がやがて 重要な役割をにならようになることは疑いないが，そ れらが世界全体の然料供給に寄与する比率は20世紀末 までは余り大きくはなりえない。しかし，西ドイッ， 南ア共和国などに和ける過去および現在の実績は今後
の合成燃料計画を推進するのに大いに役立つものであ る。そして, 米国石油企業のうち, この領域の技術開 発に熱心な企業が多い事実は注目に值いしょう。

3) 頁岩油, 砂油, 重質原油等も地域によっては （例えば米国，カナダ，ブラジル，へネゼエラ等にお (ては), きわめて多量に埋蔵され, 当該地域におけ る液体燃料供給には遠からず役立つことが期待される が，これらも世界全体の供給に寄与しらる程度は限ら れている。それは莫大な投資を必要すること, 建設に 長期間を費やさねばならぬこと, 多くの場合自然条件 がきびしく,かつ環境保全に多額の経費を要すること 等に因るものである。

4）石油産業，とくに米国石油産業は既存方式によ る天然ガス扣よび石油の生産増加を計り，2次回収技 術の向上に努める一方, 各種合成然料の生産, 精製加 工，パイプライン輸送等に関する技術分野に彼等の技 術蓄積を活かす方向で努力しつつある。(1975.6.26)

\section{文献}

1) J. D. Moody, The 9th World Petroleum Congress, PD-6 (2), "An Estimate of the World Recoverable Crude Oil Resource"

2) T. D. Adams \& M. A. Kirkby, The 9th W.P. C., PD-6 (1), "Estimate of World Gas Reserves"

3) J. J. McKetta et al., The 9th W.P.C., RP-17, "The Impact on the Petroleum Industry of Developing Alternte Sources of Energy"

4) Hans Schulz et al., The 9th W.P.C., PD-22 (4), "The Production of Liguid Fuels from Coal in Europe and Africa"

5) G. R. Hill et al., The 9th W.P.C., PD-22 (5), "Liquid from Coal in the United States"

6) 雨宮, 燃協誌, 47, 793 800 (1968)

7) H. Pichler, Herstellung flüssiger Kraftstoffe aus Kohle. Studie im Auftrag des Bundesministeriums für Bildung und Wissenschaft. Engler-Bunte-Institut der Universität Karlsruhe, 1970.

8) H. Pichler \& H. Schulz, Chemie, Ing. Tech., 42, 1162 74 (1970); H. Pichler, BrennstoffChem., 19, 226 (1938); H. Pichler et al., ibid., 48, 266 (1962); Kohle Erdgas Petrochem., 560 (1973).

9) R. D. Humphreys et al., The 9th W.P.C., PD -22 (1), “Oil Sand-Canada's First Answer to 
the Energy Shortage"

10) R. Mungen et al., ibid., PD-22 (2), "Recovery of Oil from Athabasca Oil Sands and from Heavy Oil Deposits of Northern Alberta by In-situ Methods"

11) 雨宮, 石油学会誌, 9, 691 6 (1966)
12) 富永, 燃協誌, 53, 631 9 (1974)

13) F. L. Hartley et al., The 5th W.P.C., Sect. II, No. 4 (1959)

14) Petroleum Press Service (日本版), 32, (12), 497 (1965); Hydrocarbon Processing \& Petr. Refiner, 44, (9), 185 (1965) 